\title{
Analysis of Cyberporn and Cyberprostitution Practices on Telegram Users in Medan City
}

\author{
$1^{\text {st }}$ Dedi Andriansyah ${ }^{1}, 2^{\text {nd }}$ Puspitawati $^{2}, 3^{\text {rd }}$ Supsiloani $^{3}, 4^{\text {th }}$ OK Dedy Arwansyah ${ }^{4}, 5^{\text {th }}$ \\ Karina Bangun ${ }^{5}$ \\ \{dediandriansyah@unimed.ac.id ${ }^{1}$, puspitawati@unimed.ac.id ${ }^{2}$, supsiloani@unimed.ac.id ${ }^{3}$ \} \\ Department of Anthropological Education, Faculty of Social Science, Universitas Negeri Medan, \\ Indonesia ${ }^{1,2,3,4,5}$
}

\begin{abstract}
This study reveals the practice of Cyberporn and Cyberprostitution that is developing massively on Telegram, especially for users in the city of Medan. This study uses a virtual ethnography method to observe activities that contain pornographic elements in the form of interactive chatting, pictures, and videos that are shared as culture and cultural artifacts of cyberspace. This turned out to describe the true meaning and social life of the openness of society about the pornosphere in cyberspace. The practice of cyberporn also continues to become the practice of prostitution (cyberprostitution) collectively or carried out independently with virtual or non-virtual sex services.
\end{abstract}

Keywords: cyberporn, cyberprostitution, telegram.

\section{Introduction}

Information technology, supported by all forms of platforms, was created to assist and facilitate human activities in every way, especially in communicating. So this then motivates a person or group of people to innovate to present particular types of social networks that can satisfy their users. Some even provide excellent features such as lightning applications, speed of data access, privacy, ease of sending files, and even connecting with other users randomly. These features become a characteristic of each application, and it turns out that this also gives rise to various unique communication activities in it.

One of the social media networks currently widely used as a communication platform, especially in the city of Medan is Telegram. Telegram is like being the second platform after Whatsapp that is used to communicate on smartphones. The people of Medan city still prefer to use Whatsapp to communicate with each other. However, the author observes that it is related to formal communication such as school affairs, work, scholarship information, seminars, and other legal things are mostly done on the Telegram platform. This is probably because Telegram has several pretty good features compared to other applications; for example, in Telegram, users can edit and delete messages without notification to the recipient. In addition, another feature that Telegram provides is that we can communicate with other users without having to show our phone number and can accommodate a more significant number of group members than the WhatsApp application, which is only limited to 250 people. Telegram's various features make it easier and more flexible for us to communicate and build relationships with other users [1]. 
Same as other social networks, Telegram also has chat services in messaging/chat (messenger), voice chat (calling), and also face-to-face chat (video call). However, one distinctive feature, namely group search, which can provide services to find random friends/chat partners, and then users can join quickly. However, the existence of this feature opens a very free space as a place for pornography and pornographic practices to occur on social networks (cyberporn) for fellow users (users) who are members of it.

Based on the author's observations, this practice has never even been found in other social networks such as the WhatsApp application, which is also widely used by the people of Medan. Cyberporn practices in the telegram application are also growing. They are limited to fulfilling sexual satisfaction without financing, but several courses provide paid pornographic services and lead to cyberprostitution which is filled with transactions in its implementation.

This practice can be seen from the many groups on Telegram that provide paid pornographic platforms and the ChatBot service on Telegram, which Telegram users can use as a container for pornographic videos that are being viral and commercialized. This indicates that the consumption of pornography and porno-action on Telegram users can be said to be very large and carried out massively.

\section{Method}

The type of research conducted is qualitative research with the Pornsphere approach (porn space analysis). The method that will be used in this research is the virtual ethnography method. Researchers use the virtual ethnography method to see users' social and cultural phenomena in cyberspace, as a culture and cultural artifact, cyberspace or cyber world. So that virtual ethnographic researchers can approach several objects or phenomena that occur in social media spaces and cyberspace [2].

This virtual ethnographic method is very appropriate to be a way to uncover phenomena or activities that exist on the Telegram social network. The researcher views that phenomena or actions in the form of posts and also things (writing, pictures, videos) that are shared in the telegram social network have social meanings and realities that can explain the practice of cyberporn and also the course of cyberprostitution in the analysis of the Pornsphere (porn space).

Observations made in this study are in the form of observations on Telegram social networking accounts owned by the people of the city of Medan. The researcher's initial stage was to collect as much data and information as possible to identify the Telegram social networking group, which has the characteristics of the practice of sharing posts with pornographic elements. Then also several telegram groups and users demonstrated the course of online prostitution using the Telegram social network.

After obtaining data from initial observations, the next step is narrowing the data or information needed. Namely, chat posts, pictures, and videos that contain elements of pornography, and some chats have aspects of prostitution. Then make observations on activities that describe the Pornosphere (porn space). Data from observations will be combined with data from interviews conducted and documentation.

Data collection techniques through interviews as well as virtual ethnography are both used to facilitate understanding of meaning. Both use interactive dialogical discussions, and the researcher explores the hidden meaning with the subject. The researcher verifies each knowledge before the researcher provides further analysis and provides criticism. This process 
is referred to as shared experience by Anderson and Weitz [2]. The form of interviews carried out is by unstructured online interviews using either asynchronous chat form (real-time interaction) or online discussions through applications containing chats or video calls.

The informants in this study were divided into two. First, key informants consisted of users who were members of the telegram group and were intense in sharing chat messages, pictures, and videos with pornographic elements. Second, ordinary informants consisting of passive users who rarely respond to posts but remain in the telegram group as connoisseurs of the pornography being shared.

The data analysis technique used in this research is in the form of content analysis and interpretation. Because this research is more descriptive to reveal the context through the representation of chat texts and share pornographic images or videos. According to Muhadjir [3], content analysis is a scientific analysis of the content of messages in communication. Technically, the content analysis includes:

- Classifying the signs used in touch.

- Using specific criteria as a basis for classification.

- Using certain analytical techniques in making predictions.

In line with that, according to Endraswara [4] said that the interpretation of a culture tends to view cultural phenomena as a text representation so that in research on artistic expression in texts, one can use descriptive approaches and interpretive techniques to dismantle the embedded context through the display of chat texts. And pictures and videos in the telegram group will be interpreted through this research to uncover the context of what is embedded in it. In line with that, Geertz [5] also asserts that an analogous concept in the text can be used as a procedure in interpreting a culture. Thus, interpretation can refer to the true meaning behind the symbolic representation of chat patterns and posts (shared) in the Telegram group.

\section{Results and Discussion}

\subsection{Telegram, Cyberporn dan Cyberprostitution}

Telegram is a social media application founded by two brothers, Nikolai and Pavel Durov. Telegram was first made only for iOS devices, then Android and followed by Telegram Desktop for Personal Computers. Since early January 2021, Telegram has reached more than 500 million users [9].

The increase in the number of Telegram users is inseparable from the features that Telegram provides to its users that are not found on other platforms. The features of Telegram are secret chats, integration of cellular numbers, groups, bots, and the security system in it. The secret chat feature has the same appearance and tools as standard messages, only messages in secret chat are encrypted with a client-to-client procedure. The contents of this message cannot be accessed by anyone on other devices, only by the sender and recipient on the device used. Furthermore, the message content will also be deleted in principle with a predetermined time setting.

Another feature that Telegram has is that it has a chat group that can accommodate more than 100,000 members. Not only chat groups, Telegram has another interesting feature, namely Chat Bot. Bots are third-party applications that run inside Telegram. Users can interact with bots by sending users messages, commands and inline requests. Chat Bot can bring together one user with other users randomly to be able to communicate with each other. In 
today's technological developments, there are many studies that use chatbots as virtual assistants or shop assistants. Chatbots are generally used to automatically reply to incoming messages. However, as technology develops, chatbots can be used as a mix and match medium between one user and another.

The overflow of sexuality through digital media is categorized as a fact that continues to grow following every new technological feature that appears. It is not only to satisfy the needs of sexuality in the form of displaying images, videos, chats, and other forms but also in the form of commercialization in fulfilling this biological need. The cyberspace space facilitates various applications in communication technology. Social media that is in the sophistication of information technology opens the limits of free will (sexuality), which has an addictive impact [6].

Technological developments such as being a breath of fresh air for the spread of pornography, especially in the cyber world or commonly known as cyberporn. Gordon and Kraus explain that sexual exploitation in virtual spaces such as cyberporn which is patterned in the form of Video Calls, live streaming videos, or sharing photos and videos, is considered to provide experiences and sensations in the release of bodily pleasures, and this is part of the presence of globalization, regardless of whether he becomes a massive social evil or something that is needed [7].

The role of computer users (consumers) also helps in the distribution of cyberporn. Every time a consumer logs in (to a web), their transaction assists the pornography in compiling a database of information about their buying habits and sexual tastes. The distribution of pornography in the cyber world can be done by groups or individuals, each computer user. More sophisticated computer pornography uses these databases to develop mathematical models to determine which images they should aggressively market - such translation results in how pornography marketing can be accepted in a virtual society for consumption.

Research conducted by Hildawati[8] describes so many forms of online sexuality outlets spread using social media such as Facebook, Twitter, Instagram, and WhatsApp. The records of online sex consist of Video Call Sex (VCS), Phone Sex (PS), and Chat Sex (CS). VCS online sex activity using Video Call media. While Phone Sex (PS) is a sexual activity carried out through telephone conversations, there are also Chat Sex (CS) activities that use chat media or text messages. Women and men carry out perpetrators of online sexual activities. Providing sex services for women is money, so they charge a fee for these activities. Meanwhile, men open online sex services to seek satisfaction and have the slogan "equally satisfied," so money is not the primary goal.

Although based on the research above, it is explained that the basis of online sex or sexual activity in the cyber world (cyberporn) is because of the basis for the release of bodily pleasures, but according to Yulius [7] in his book entitled Serious Conversations about Contemporary Sexuality, even though the main goal is the basis for the enjoyment of sexuality, but many of these online sex practices have developed into commodities filled with economic transactions and opportunities for prostitution businesses both online and in the real world (cyberprostitution).

The patterns of prostitution that are carried out in this virtual space are also increasingly being penetrated using advances in social media information technology. The practice of cyber prostitution is indeed in the spotlight of law enforcers (cybercrime) in the police, but the massiveness of the course makes it challenging to trace and enforce the law. Various social media platforms, especially those with chat features, are the right places to process and sell prostitution services. The most surprising thing is to use the telegram platform, which is considered new and is often used for positive interactions. 
The practice of online sex in the form of cyberporn and cyber prostitution is getting attention from social science researchers who focus on the cyber world. Like the research conducted by Prima Angkupi [10] with the title "Cyberporn Paradigm in the Perspective of Legal Culture and Religion," the results of his study explain the weaknesses of legislation and technological advances supported by deficient public awareness of the law, resulting in difficulty in overcoming cyberporn crime.

Furthermore, a paper with entitled "Online Prostitution and the Existence of Government Power" showed that online prostitution has shown that their existence is getting stronger in cyberspace because their relationships make their business more strategic and increasingly challenging to intervene by [11]. In addition, research conducted by Euis Ratnaningsih, Abd. Basit [12] "Online Prostitution Cases in the Media Frame." The print media of the daily newspaper Radar Cirebon was one of the reports on the online prostitution case. The daily newspaper Radar Cirebon reported on prostitution geo-location-based online.

The emergence of the case of the artist Vanisa Angel who was involved in online prostitution has further increased research related to the topic of the artist as conducted by Elsa Noviyanti, Dewi Maria Herawati [13] "Women's Representation in Reporting on Vanessa Angel's Online Prostitution Cases at Suara.Com and Kumparan.Com." The results of his research explain that women have been represented as the dominant party, the main actors and triggers for online prostitution cases because they are considered as parties who make themselves a commodity to be sold by pimps to men who need sex services.

\subsection{Cyberporn on Telegram (Sexual freedom in cyberspace)}

Telegram is a platform for communicating that has features not much different from WhatsApp. However, Telegram has unique and advanced features that can't be found in other applications, such as hiding phone numbers, IDs, profile photos. Then the feature of sending pictures or videos with a larger size, the feature of pulling messages on both sides (sender and recipient), the feature of sending photos that are deleted automatically from the specified time, the feature cannot take screenshots on the Telegram chat page, group chat feature that does not limit the number of group members in it, unlike WhatsApp which has a limit of only 250 users who can join a group. In addition, in the Telegram group, there is a feature called the Bot feature. This feature has the advantage of bringing together users randomly without the need to know the identity of these users and then being able to make video calls, chat, and voice notes as is commonly used on other communication platforms.

The easy group search provided by Telegram turns out to give a very free space for users to randomly browse groups on Telegram, especially those that contain pornographic content. The term pornography is etymological; pornography comes from elements of the Greek language, namely porne, which means prostitute, and graphein, which means writing or pictures. Then these two words combined into the phrase pornographic, which has a complex meaning, namely writing about prostitutes. Later in its development, pornography is not just describing prostitutes, but into all kinds of works intentionally made to stimulate lust.

Hendri Yulius, whose writings have focused heavily on the pornography space in the cyber world, known as cyberporn. In his book entitled $\mathrm{C}^{*}$ abul, he explains that the internet and the digital space are the keys to unlocking more varied works. In providing virtual fantasy porn (cybersex), that can stimulate lust. The variety of pornographic works cannot be separated from the sexual fantasies of different people, and not just pornography, the internet which makes it easy to interact on this communication platform, also makes it easier for pornographic actions to be witnessed live [7]. 
On the Telegram platform, everything that facilitates the intensity of pornographic activity in the cyber world (cyberporn) is the presence of the Bot feature. This feature makes it easier for a Telegram user to search for these sex groups by typing a few words in the search column such as sex, porn, passionate (desire), and several other keywords that contain elements of sexuality. Then quickly, this Bot feature will provide group options that the user can enter, even connect with other, more specific groups within the group. Like a unique bot for storing pornographic materials that can be accessed via a link shared in the previous group. Within these groups, thousands of users have joined and communicated and shared pornographic content or did pornography. From the results of the author's observations, there are several telegram groups in which many members of the community have joined users from the city of Medan. Like the @ INDOCL group who have joined in it $1.6 \mathrm{~K}$ or approximately 1,600 subscribers (as for users), @LINKBOKEPMANT who have joined 439.2K or more or less 439,200 subscribers, then the @NGENTWO telegram group which already has 18,530 subscribers, and other groups that when searched in the search group section will appear. If we observe it not in-depth, we think that the spread of pornography seems to be carried out massively (hidden). Still, if we follow it by joining the group, we will know that the spread that contains pornographic elements is distributed freely and openly. As if sexuality is no longer a taboo subject and so free to talk about it.

A bot is an algorithm (machine) created for special needs, for example, as a network tester with a working system to provide feedback or reply messages when we send a message to the Bot to provide information if the Telegram platform on our cellphone has a running connection. There are many kinds of bots created on Telegram. One of them is a bot with an algorithm that brings together one user with another user without knowing any identity such as name, photo, id, cellphone number, or whatever it is about user privacy in the connection. There are several bots of this type with similar algorithms that bring together users with other users. For example, the Bot from @ chatbot is called the Anonymous Chat Bot Bot. The Bot feature provides freedom of expression for its users because any norms or regulations do not bind it.

One form that supports this activity is the feature of Telegram, which allows each user to create an ID with any name and can be edited at any time so that users who have done things considered taboo can remove traces very easily. According to @ Kibboo, who uses Anonymous, why dare to expose his "cock" photo because it doesn't show any identity. So that $@$ Kibboo freely gives his "photos" and looks for female friends who are "of the same frequency" with him, namely women who are in lust so that they want to exchange photos or similar activities to vent each other's passion.

Telegram users familiar with the Bot feature are already familiar with the phenomenon of "looking for great friends" in Bots. This is evidenced by the acknowledgment of several users who play Bot about this. Like @ syilang who to the point says, "are you a passionate man or not?" at the beginning of the conversation, which shows that he already knows that in the Bot, there are people who are looking for great friends. Another account with the ID @ gadibacagunakanh also said that he often met men looking for great friends on the Telegram Bot feature. The search for great friends does not look at the time, at any time, and under any conditions, he always finds users looking for friends to do this.

Bots not only help in that regard but are also vital in spreading pornographic content in telegram groups. The author observes the types of groups that share pornographic content on telegram. This group is the "place" for cyberporn activity to be divided into three types of groups. First, free groups, namely groups that provide pornographic content that can be accessed freely by customers. But usually, in this group, the content that is shared is not 
currently viral. Even content that is shared is only for a short time. Second, namely Paid group. This group is known as a VIP group. All customers can join, but to get pornographic content usually will be asked for a fee that must be transferred. This is because the content being shared is of long duration, the latest or that is being virally sought after on social media. The third is the homosexual group. This group was initially closed and only the admin as the controller of this group, but due to the increasing number of customers who joined, this group dared to show its existence by being more open to its users. One of the most popular accounts for same-sex sexual orientation (homosexuals) is a group account called @BOYS UKE SEME. The choice of the name Uke Seme are words related to the division of roles in undergoing homosexual relationships. Seme is a name for "those" who plays a male role in a relationship, while Uke is a name for those who play a female role where Uke is a more feminine type and has a gentle character to his partner. The UKE SEME BOYS group has approximately 4,038 members or users who join it. The routine activity carried out by group members is the voice chat. Not infrequently, they also show each other selfies and even voice recordings of sighs that are reciprocated or done in real-time via the group phone.

Meanwhile, when viewed from the characteristics of group management, the group sex is divided into two parts, first, a passive group, where only admins can share information containing pornographic elements. At the same time, users cannot chat and send anything. The second is an active group where admins in the group provide flexibility for customers/users who are members to interact in two directions, such as having sex with other users and sharing content that includes pornography and pornography. The contents that are shared include:

Photos. Sharing photos usually only occurs inactive groups and begins with sex-nuanced chats between men and women. Some male and female users who chat with each other will ask each other to exchange photos, from photos of faces to pictures of each other's genitals. This is done not only as an increase in lust in sex chat or commonly known as chaturbate, which is a sex chat activity that leads to mutual masturbation but also to ascertain the true identity of the chatting partner. Because it is often found in fake account groups, who intend to find entertainers by pranking other users. The photos sent are usually real photos, but there are also manipulations from porn stars or pictures taken from other social media.

Porn Videos/Mini Videos. The activity of sharing porn videos or mini porn videos is never in the form of total videos. Usually, mini videos are only 1 minute long and are just video footage. Sharing these mini porn videos is generally done in passive groups. This is because admins usually have many collections that can be transferred to please group users. However, users/customers still can't do other activities and wait for what the admin shares. Then the admin every day will share a mini video along with a link which, when clicked, will be directed to a unique bot where the full video is stored.

The video usually sent depends on the characteristics of the group's name, like the account @ JapaneseV3 which has 7.5K or more or less 7,500 subscribers. The admins in this group specifically share porn videos in which Japanese men and women actors and artists. The group admin always sends the latest videos and tutorials on downloading these videos in the group. In addition, there are other accounts, such as the @ AsupanGabutAsik account which has $233.8 \mathrm{~K}$ or approximately 233,800 subscribers, and the admin of this group shares collections of Indonesian porn videos explicitly. One customer with the account name @ Pandendoi who is a telegram user informant from the city of Medan and has long joined these groups, said that the choice of which group to follow usually depends on the direction of their sexual satisfaction/enjoyment (fetish). -each individual. According to him, some choose 
to join a particular telegram group to share Japanese sex videos, Indonesian, European sex videos, school children, women dressed in certain religions, or even lead to same-sex sexual orientation.

Link. Not only sharing photos and mini porn videos in the group on Telegram and share links from a collection of porn videos with a long duration (total duration). Although usually in sharing mini porn videos, the admin will also include links such as FullVideolink or JandaVVIP which when clicked will connect to a bot that specifically stores all porn videos. To avoid bots being banned by Telegram for violating the law (cybercrime), the link will usually direct to bots that keep certain website links. On this website, all collections of pornographic videos that can be downloaded are collected. But some websites are paid. This means that users have to make money transfer transactions to specific accounts through DANA, GOPAY, or certain banks with varying price benchmarks. Then the user/customer will receive a particular code in advance to get access to watch or download the various porn videos.

Like a group with the account name "ASUPAN GABUT ASIK." All the photos and mini porn videos that are shared always include a link that will later be forwarded to the "SAVE FILE VIDEO" Bot. Among them are the latest viral video links, Indo/Malay Hijab Bokep, Japan Bokep, American Style Porn, Indo Pride Local Porn, Live Record, and so on. If the user wants to get the video, then click on the start sign. It will automatically enter into the Bot various chats from the admin in which there is a link that will continue on the website filled with multiple porn videos.

\subsection{The practice of cyberprostitution on Telegram}

The spread of pornography through cyber/digital media (cyberporn) is not the only worrying phenomenon because its development is so massive. Still, other phenomena follow, such as prostitution, which is also carried out through cyber/digital media. Cyber prostitution comes from two English words, namely prostitution, which comes from prostitution. Prostitution is understood as having sexual relations by ignoring emotional feelings and based on payment. In contrast, cyber comes from the word cybernetics, defined as remote control (robot/system) in cyberspace. So that cyber prostitution or cyber prostitution is complexly understood as a practice/activity to fulfill sexual needs through digital media platforms with transactional first. This transaction is carried out between the first party who wants to meet their sexual needs to the second party who gets the benefits. Prostitution has been around for a long time. But always have a different system in each place (localization) [14].

Prostitution is the oldest profession in the world. Prostitution has existed since the community existed as a unit until now. Even prostitution has moved freely through the help of various digital media platforms. Of course, conventional prostitution will be very different from the pattern of prostitution in the cyber world. Sanger [15] explains in his book The History of Prostitution which is very popular among prostitution reviewers, that the differences in patterns and systems in prostitution depend on the arena or localization. Like Greece in the heyday of Athens, it was divided into various forms, including religious prostitution, which was carried out in hidden temples. Prostitutes were required to wear clothes with colorful floral motifs as a symbol of identity, and the emergence of the placement of prostitutes as Hetaire or mistresses. They, at that time, can shift the position of good 
women. This phenomenon arises because prostitutes have an essential role as service providers in political negotiations.

Patterns in prostitution are also growing, especially in the digital (cyber) arena. Meetings between men and women without knowing each other are so easy to happen. On the Telegram platform, there are various forms of patterns or prostitution activities; initially, this pattern was a form of mutual love, or what Pandiangan[16] called in his work entitled Because we are all crazy about sex, namely as a search for free sex. through the application. However, the formed pattern opens up very free opportunities for negotiations and transactions to fulfill these sexual needs. These patterns include:

Friends with Benefits. Friends with Benefit commonly abbreviated as FWB on Telegram users, is a date with mutual benefits. The Bot feature makes it easy to meet these men and women in a group found randomly. The term FWB is indeed pinned on men and women who are looking for friends who both want to vent their sexual desires (sange). They will chat with each other through chat in the group to the point through lists which are the characteristics of couples who want to establish FWB. The list of attributes like this form is called the tap method. For example, a woman wants her FWB partner who has a sensual sigh, young age, ideal body posture, can keep secrets, can be contacted at any time, and so on, and then she will list the types she wants. Some men who feel they can fulfill the woman's wishes will reply to the woman's chat in the group.

Couples who have established FWB will then meet each other's sexual needs in various ways, such as chat to masturbate or chaturbate, Video Call Sex, and have direct sexual intercourse by making an appointment with each other in advance. At first, this kind of relationship was established because of the sexual desire that they both wanted to vent without shame. However, this FWB pattern provides opportunities for prostitution in the cyber world. For example, the informant using the @Dani account who also has FWB and has multiple partners, explained that sometimes women often ask for tariffs, but not in the form of money transfers, but credit transfers or with other hidden things such as topping up GoPay balances, LinkAja, OVO, DANA and so on. So it seems like it's not a payment or a transaction, but actually, there are benefits that the woman gets. Sometimes the informant had an experience when the FWB was conducted in the form of a face-to-face meeting, and the woman often asked about the cost of food and the cost of going home to her male partner. Still, according to the informant, it was also done by her friend who is a man, where his friend always asked for money. from his female partner for similar reasons.

One Night Stand. Not much difference with Friend with Benefits (FWB), One Night Stand is the same activity with the same pattern of finding friends, but reluctant to have a status called friends. One Night Stand emphasizes more that it is necessary at the same time. It will not communicate again when the sexual activity is finished. Some people who make One Night Stand prefer to connect in a bot form or not to provide their account ID to join the account personally.

Communication using the bot form does not leave any traces because when finished doing the desired activity, the user can skip or leave the interlocutor. Some users also carry out one Night Stand by connecting in personal chat (providing ID). The choice to provide ID tends to be done because, in the bot menu, there are no voice calls, video calls, automatic message destroyers, or message pullers. However, One Night Stand users who have provided ID will block their playmate's number when the activity is finished. The opportunity for transactional occurrence is also not directly asking for money. But it can be in the form of credit payments, 
which is the same as FWB. According to the @ Desdoy account, costs can also be in renting a safer hotel room.

The one-night stand is indeed more impressive to maintain privacy and identity. Based on his experience, the @Dendoy account also had female acquaintances who always wanted to wear masks even during sex. Then after having sex, he was asked to leave the woman in the room and go home first. So that the woman can enjoy hotel services until the rental time is over. After that, the @Dendoy account will be blocked by the woman, and they can no longer interact.

Video Call Sex (VCS). Video calling sex, commonly known as VCS by telegram users, is one method of releasing sexual desires between fellow users, whether in FWB or One Night Stand. Usually, the release of sexual desire begins with an intimate chat and continues to send photos of each other's bodies and genitals. Then it will continue to the final stage, namely doing VCS. Often to get to this final stage, many of these couples ask for forms of payment such as credit or request to buy internet packages. After this is done by one party (usually a man), the woman is willing to share VCS with a body that is not wearing clothes.

This kind of behavior was previously considered an abnormal activity or commonly known as Exhibitionism behavior. Behavior that shows nudity and shows his genitals without shame. Even get pleasure from it. Pambayun[17] calls it a form of digital intercourse that gives and gets pleasure through activities showing increased sexual desire. VCS does provide an opportunity to achieve satisfaction in the male and female partners. Usually, they will ask each other to do something that can provoke their sexual desire (libido) to increase. Such as sighing, using sex toys, uniformed waiters, and so on that sometimes unexpectedly can increase sexual desire.

All forms of fulfilling sexual needs carried out by couples intertwined by the telegram platform seem to be by reality. They practice and demonstrate whatever is required to increase the sexual desire of each partner. According to one female informant with the account @ GeulisMau who was interviewed online via the telegram application, she explained that not all of these practices were carried out based on genuinely enjoying it or feeling the turmoil of complimentary sexual desires. But they are very good at role-playing and show as very aroused and feel satisfied (satisfied). Not infrequently, this is done to maintain the relationship in the FWB that has been established.The virtual display gives the impression of complex sexual satisfaction, and they get. This practice is just an exaggerated manipulation. Baudrillard, in his book entitled Berahi, explains that seduction operates through deception and drowns all human beings through sign simulations (simulacra) that present exaggerated pseudo-realities (hyperreality)[18].

The reality of having digital intercourse by one of the parties, such as a very sensual sigh due to an increasingly passionate libido, turns out to be a manipulation of an exaggerated pseudo-reality (hyperreality) to keep the relationship going. In the pornosphere, each individual and their partner are so wild to show their sexual desire through any practice. Still, the madness and wildness are not always the actual reality, but a fictitious and manipulative reality.

Based on the author's observations, the pattern in cyber prostitution (cyber prostitution) through the telegram platform can be divided into two types: (1) Solo managerial type, which is managed by the individual himself and is usually dominated by women. The pattern of getting softer benefits and not seeming to peddle themselves like prostitutes/prostitutes who are localized for prostitution. Not it is directly targeting a certain amount of tariffs if you want 
to get sex services from them. But it is starting with a sensual conversation, giving a sense of comfort, and then asking to be filled with credit or balance on Gopay and other applications. The amount is indeed not as large as hiring a prostitute in localization. As for the benefits of this solo managerial, the woman's benefits are intact for her. This is not a problem because the benefits obtained are only side-by-side and prioritize satisfying each other's sexual desires among FWB partners or One Night Stands. This means that it is no longer divided among the agents or pimps who carry it. The only drawback in this type is the number of benefits that will not be as large as the number of prostitution types in the managerial team, but it is safer (safety) from raids. Because it seems consensual, especially prostitution in the form of a collective is more vulnerable to being investigated by the police. (2) The type of managerial team, this type is managed in a collective form. There is a conventional form of prostitution in it, where there are pimps, and there are prostitutes. The pimp (pimp) will prepare everything from finding a man on the telegram for the prostitute. Then the pimp will determine the rates and the place where the sexual services are performed. Usually, the rates are much more than double managerial. Pimps (pimps) usually already have relationships with men who are rich and have positions. However, what is lacking in the managerial team is that the potential for prostitution to be exposed by the police is much greater. Because there are so many actors in it, the whole thing will be revealed if one of them is caught. This often happens in cases of artist prostitution in Indonesia.

\section{Conclusion}

The results of the study entitled Analysis of cyberporn and cyber prostitution practices on Telegram social network users in Medan City concluded that cyberporn practices in the Telegram social network could occur because of the Bot feature that is unique and only owned by Telegram. So that Medan city users can connect in sex groups that can be searched randomly. Then there are two types of sex groups on Telegram, namely active groups and passive groups but with the same activity, namely sharing porn photos, mini porn videos, and also links that will direct you to special bots for full porn video collections. The practice of cyber prostitution (cyber prostitution) in the telegram group is very free to occur with various distinctive patterns such as Friends With Benefit (FWD), One Night Stand (overnight friendship) and is facilitated by the form of sex chat (chaturbate) and Video Call Sex (VCS). Even the pattern of transactions in cyber prostitution (cyber prostitution) has developed into a transaction that seems simple and easier to obtain, namely in the form of buying credit, package quotas, topping up Gopay, LinkAja, DANA, and other platforms. Hopefully, more research on the culture of sexuality in the cyber world can be done. So that it can be a reference in understanding the cultural activities of users in cyberspace.

Acknowledgments. The authors would like to thank the Institute for Research and Community Service (LPPM) the State University of Medan for funding assistance in this research. So that this research about Analysis of Cyberporn and Cyberprostitution Praktices on Telegram Users in Medan City can be completed. 


\section{References}

[1] Nasrullah R. Khalayak Media Identitas, Ideologi Dan, Perilaku Pada Era Digital. Bandung: Simbiosa Rekatama Media; 2018.

[2] Ariesta AP. Etnografi Virtual sebagai Metodologi Penelitian Berbasis Virtual. Surabaya: Universitas Airlangga; 2018.

[3] Muhadjir N. Metodologi Penelitian Kualitatif. Yogyakarta: PT Bayu Indra Grafika; 2016.

[4] Endraswara S. Metode Penelitian Folklor "Konsep, Teori, dan Aplikasinya." Yogyakarta: Med Press; 2009.

[5] Geertz C. Tafsir Kebudayaan. Yogyakarta: Kanisius; 2012.

[6] Lanier J. Ilusi Media Sosial Sepuluh Argumen Tentang Paradoks Medsos. Yogyakarta: Cantrik Pustaka; 2019.

[7] Yulius H. Tidak Semua Seks itu Jorok. Jakarta: PT.Gramedia; 2020.

[8] Hildawati. Seks Onlen, Media Sosial, dan Gender. J Emik. 2018; 1:25-30.

[9] Nurudin. Tuhan Baru Masyarakat Cyber di Era Digital. Malang: Aditya Media Publishing; 2017.

[10] Angkupi P. Paradigma Cyberporn Dalam Perspektif Budaya Hukum dan Agama. J Cita Huk Fac Sharia Law UIN. 2017; 5(1):75-88.

[11] Yudha T, et al. Prostitusi Online dan Eksistensi Kekuasaan Pemerintah. J Sos Soedirman. 2018; 2(1):1-21.

[12] Ratnaningsih E, Basit A. Kasus Prostitusi Online Dalam Bingkai Media. J Dakwah dan Komun. $2019 ; 10(1): 123-135$.

[13] Noviyanti E, Herawati DM. Representasi Perempuan Pada Pemberitaan Kasus Prostitusi Online Vanessa Angel Di Suara.Com dan Kumparan.Com. Majalah Semi Ilmiah Populer Komunikasi Massa. 2020: 35-40.

[14] Bunga D. Prostitusi Cyber. Bali: Udayana University; 2012.

[15] Sanger WW. History of Prostitution. Yogyakarta: Forum; 2020.

[16] Pandiangan E. Sebab Kita Semua Gila Seks. Yogyakarta: Buku Mojok Grup; 2021.

[17] Pambayun EL. Birahi Maya. Bandung: Nuansa; 2010.

[18] Baudrillard J. Berahi. Jakarta: PT Buku Seru; 2018. 